\title{
ACCUMULATION OF PHENYLPROPANOIDS IN GREEN AND RED PEPPER FRUITS OF SEMI-HOT CULTIVARS Capsicum annuum L.
}

\author{
Małgorzata Materska, Irena Perucka \\ Department of Chemistry, Research Group on Phytochemistry, University of Life Sciences, \\ Akademicka 15, 20-950 Lublin, Poland \\ e-mail: malgorzata.materska@up.lublin.pl
}

Received: 12.09.2010

\begin{abstract}
The aim of the present work was to determine differences in $C$ and $O$ glycosides of flavonoids, derivatives of phenolic acids, as well as capsaicinoid content in two semi-hot pepper cultivars, cv. Tornado and Tajfun. Fruits were harvested at the green and red maturity stages. Flavonoid and capsaicinoid fractions were isolated on Sep-Pak C18 cartridges with $40 \%$ and $70 \%$ methanol-water solutions, respectively. The chemical composition of both fractions was determined by HPLC method using standards of phenolic compounds obtained in the earlier work and the capsaicin standard. The flavonoid fraction contained glucose esters of phenolic acid, mainly ferulic and sinapic acid, as well as derivatives of flavonoids, quercetin, luteolin and apigenin, which occurred as $O$ - and $C$ - glycosides with glucose, rhamnose, and apiose. The capsaicinoid fraction contained mainly capsaicin and dihydrocapsaicin. It was found that in green fruits flavonoid $O$-glycosides were the predominant phenolics, while in red ones derivatives of phenolic acids. A higher loss of $O$-glycosides of flavonoids than of $C$-glycosides was observed during the maturation of the fruit of semi-hot pepper cultivars.
\end{abstract}

Key words: Capsicum annuum $\mathrm{L}$; $C$-glycosides, $O$-glycosides; flavonoids; capsaicinoids

\section{INTRODUCTION}

In the recent decades, we can observe the great interest of scientists in the influence of food intake on human health. It has been found that diet rich in fruit and vegetables decreases the risk of cardiovascular and neoplastic diseases and delays the aging processes (R o w l a n d, 1999). This is defined by the term "functional food" applied to food that evidently has a good influence on human health, and "nutriceuticals" used for dietary compounds that promote health. Many food components are recognized as nutriceuticals, among them vitamins, carotenoids, and phenolic compounds (F a s and F a u cher, 2002). Pepper fruits are very popular due to their health-promoting properties associated with their high content of vitamins $\mathrm{C}$ and $\mathrm{E}$ that are present in high concentration in various pepper types (How ard et al. 2000; Marin et al. 2004). The second group of biologically active compounds of pepper are carotenoids, among them $\beta$-carotene and $\beta$-cryptoxanthin with provitamin A activity ( Horn e ro-Mendez et al. 2000; Minguez-Mosque$r$ a et al. 2000).

Phenolic compounds are a group of plant secondary metabolites important for nutritional and therapeutic applications (S h e t t y , 2004). They exert beneficial effects in a multitude of disease states, including cancer, cardiovascular diseases, and neurodegenerative disorders ( $\mathrm{Harborne}$ and $\mathrm{Wi} 11 \mathrm{iams}$, 2000). The chemical activity of phenolic phytochemicals has been shown to be associated with antioxidant action in biological systems; they act as scavengers of singlet oxygen and free radicals ( $\mathrm{H}$ a r b o r n e and Willi a m s, 2000). The ability to quench free radicals arises from the chemical structure of phenolics. A number of studies have demonstrated the relationships between their structure and antioxidant activity (R i c e-Evan s et al. 1997). It has been found that the activity of these compounds generally depends on the presence of hydroxyl substituents and their position in the molecule (Rice-Evans et al. 1997; B urda and Oleszek, 2001). In pepper fruit they occur as $O$ - and $C$-glycosides of flavonoids and glucose esters of phenolic acids (Marin et al. 2004; Materska and Perucka, 2005).

The stimulation of synthesis of protective secondary metabolites results from plant adaptation to biotic and abiotic stresses (S h e t ty, 2004). Phenolics play an important role as cellular support materials and the increase in the levels of these compounds is a response to infection, acting as a precursor for synthe- 
sis of lignin, suberin and other polyphenolic barriers (Y a l p a n i et al. 1994; D i a z et al. 1998).

The hot taste of peppers arrises from capsaicinoids, alkaloids specific for the Capsicum genus. According to the capsaicinoid content, peppers may be classified as hot, semi-hot and sweet. Capsaicin, the main compound of capsaicinoids, has been studied extensively to exploit its potentially therapeutic value (Long and Medeiros, 2001; Kogure et al. 2002; S z o lc s a n y i, 2004). It is considered as an analgesic and antiinflammatory drug (S z o l c s a n y i, 2004). To date, several studies have revealed the ability of capsaicin to inhibit events associated with the inhibition, promotion and progression of cancer (M o r r e et al. 1996; L e e et al. 2004).

The biosynthesis of phenolic compounds consists of two central pathways: the shikimate and the common phenylpropanoid pathway from L-phenylalanine. The vanillylamine moiety of capsaicinoids is also biosynthetically derived from L-phenylalanine ( $\mathrm{S} \mathrm{u} \mathrm{k} \mathrm{r} \mathrm{a} \mathrm{s} \mathrm{n} \mathrm{o}$ and Y e o man, 1993). The convergense of biosynthetic ways of phenolic compounds and capsaicinoids may lead to the synthesis of one group of compounds at the cost of the second one. This situation was confirmed in the hot pepper cultivars, where the synthesis of capsaicinoids occurred at the cost of phenolic compounds ( $\mathrm{M}$ a ter s k a and P e r u cka, 2005).

The aim of the present work was to determine the relationships between phenolic acid, flavonoid and capsaicinoid accumulation during fruit maturation in semi-hot pepper cultivars. Flavonoids were investigated as $O$ - and $C$-glycosides. In literature there is little information about changes in the accumulation of these compounds in ripe and unripe pepper fruits. For this reason, the relation between $O$ - and $C$-glycosides in green and red maturity stages of pepper fruits was taken into account.

\section{MATERIALS AND METHODS}

The fruits of two semi-hot pepper cultivars: Tornado and Tajfun, were obtained from the experimental field of the Department of Vegetables of the University of Life Sciences in Lublin (Poland). For analysis, the pericarp of pepper fruits at the two maturity stages: mature green (fully developed but not colored) and red ripe (completely red skin), was taken. Immediately after harvest, the pericarps were cut, freeze-dried and stored at $-20^{\circ} \mathrm{C}$. Dry matter of fresh pericarps was assayed using the dryer method.

The freeze-dried pericarps of pepper were homogenized with $80 \%$ ethanol and after solvent evaporation two fractions of phenylpropanoids were isolated by solid phase extraction (SPE) on a Sep-Pak C18 (Waters) column. The procedure used for the isola- tion of phenolic compounds is described in detail in $\mathrm{Materska}$ and Perucka (2005). Both fractions were evaporated until dryness at $40^{\circ} \mathrm{C}$ and equilibrated to $1 \mathrm{~cm}^{3}$ and analyzed by HPLC method.

The qualitative and quantitative analysis of particular components of the fractions was made by highperformance liquid chromatography (HPLC) on the WellChrom chromatograph (Knauer) with the UV detector. Separation was done on a column filled with modified silica gel RP-18 (Vertex Eurosil Bioselect 300 $\AA, \varnothing 5 \mu \mathrm{m}, 4 \times 30 \mathrm{~mm}$, endcapped). Particular derivatives of flavonoids and of phenolic acids were quantitatively determined with the use of standards of phenolic compounds isolated from pepper fruit by means of preparative liquid chromatography and identified by spectral methods NMR and MS, according to the method of S t o c h m a l et al. (2001) and M a te r s k a et al. (2003a; 2003b). The quantitative determination of the capsaicinoid fraction was conducted by the HPLC method in the isocratic system with $55 \% \mathrm{CH}_{3} \mathrm{CN}$ (Merck), with the flow rate of $1 \mathrm{ml} / \mathrm{min}$ and detection at $280 \mathrm{~nm}$. The capsaicin and dihydrocapsaicin content was determined on the basis of the standard capsaicin solution also containing dihydrocapsaicin (Merck).

The statistical analysis compared the results obtained over the three years of the experiments done in three replications. For each set of data, the standard deviation was calculated and Tukey's multiple test was applied to evaluate the significance of the differences between the means, assuming a 5\% error of probability. To define correlations between sets of data, the correlation coefficient was calculated. The calculations were done using Statgraphic v 3.0 for Windows software.

\section{RESULTS}

The chemical composition of flavonoids with phenolic acid fractions was determined by HPLC method (Fig. 1). The analyzed derivatives of phenolic acids were as follows: trans-p-feruloyl- $\beta$-D-glucopyranoside and trans- $p$-sinapoyl- $\beta$-D-glucopyranoside. The following belonged to $O$-glycosylated flavonoids: quercetin 3-O- $\alpha$-L-rhamnopyranoside, lutoeolin 7-O-[2-( $\beta$-D-apiofuranosyl)- $\beta$-D-glucopyranoside], and luteolin 7-O -[2- ( $\beta-\mathrm{D}$-apiofuranosyl)-4- $(\beta-\mathrm{D}$ glucopyranosyl)- 6-malonyl]- $\beta$-D -glucopyranoside. $C$-glycosylated flavonoids were represented by luteolin 6- $C$ - $\beta$-D-glucopyranoside- $8-C$ - $\alpha$-L-arabinopyranoside and apigenin 6- $C$ - $\beta$-D-glucopyranoside- $8-C-\alpha-$ L-arabinopyranoside.

The Tornado cultivar was characterized by higher levels of phenolic derivatives than Tajfun (Tables $1,2)$. It was found that luteolin derivatives were the main flavonoid in pepper fruit of both semi-hot cultivars (Table 1). During fruit maturation, considerable 

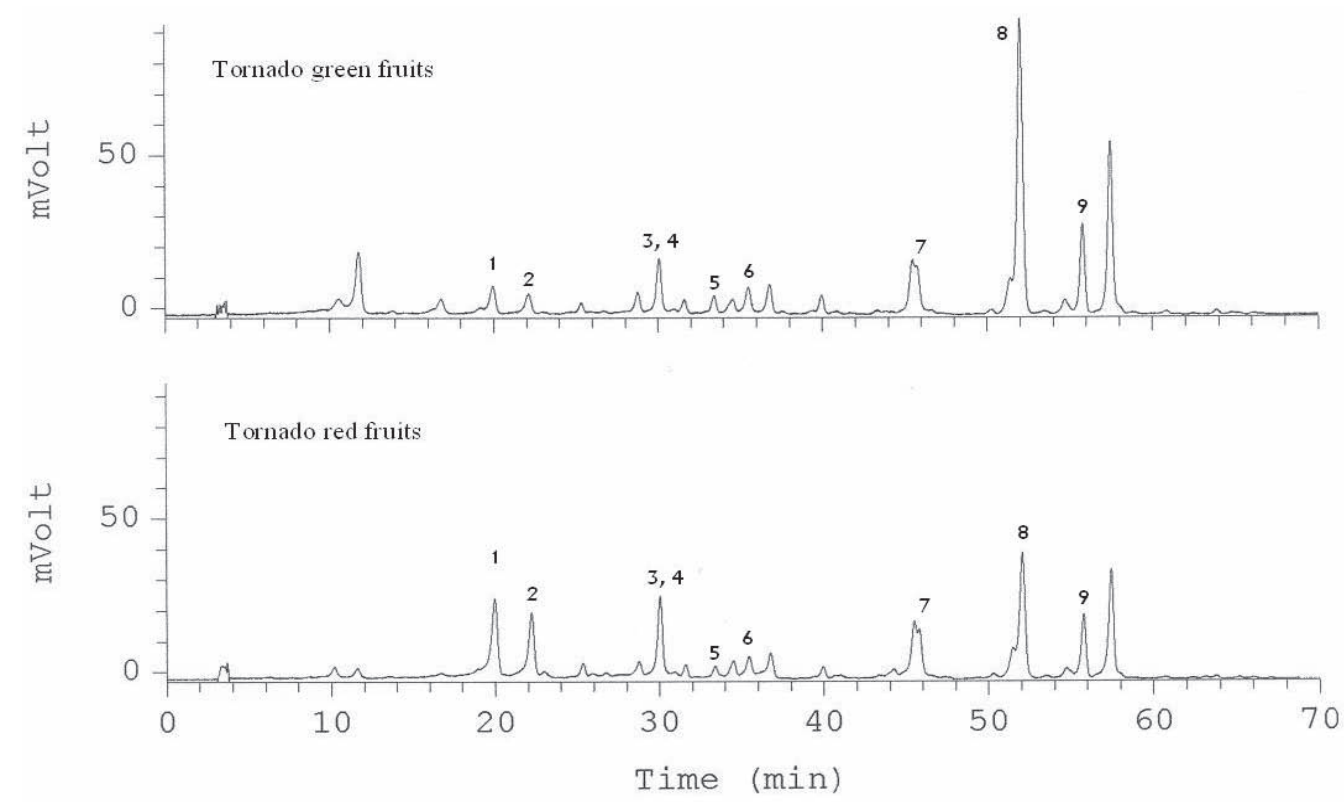

Fig. 1. HPLC-UV chromatogram of phenolic compounds in flavonoid fraction from green and red fruits of cv. Tornado. Peaks: 1: trans-p-feruloyl- $\beta$-D-glucopyranoside, 2 :trans-p-sinapoyl- $\beta$-D-glucopyranoside, 3 :quercetin 3- $O$ - $\alpha$-L-rhamnopyranoside7-O- $\beta$-D-glucopyranoside, 4: trans-p-ferulylalcohol-4-O-(6-(2-methyl-3-hydroxypropionyl) glucopyranoside, 5: luteolin 6- $C$ - $\beta$-D-glucopyranoside-8- $C$ - $\alpha$-L-arabinopyranoside, 6: apigenin $6-\beta$-D-glucopyranoside- 8 - $C$ - $\alpha$-L-arabinopyra-noside, 7: lutoeolin 7-O-[2-( $\beta$-D-apiofuranosyl)- $\beta$-D-glucopyranoside], 8: quercetin 3- $O$ - $\alpha$-L-rhamnopyranoside, 9: luteolin 7- $O$ [2-( $\beta$-D-apiofuranosyl)-4-( $\beta$-D-glucopyranosyl)-6-malonyl]- $\beta$-D-glucopyranoside (according to Materska et al. 2005)

Table 1

The content of flavonoid derivatives in semi-hot pepper cultivars at two maturity stages $\left(\mu \mathrm{g} \mathrm{x} \mathrm{g} \mathrm{g}^{-1} \mathrm{fw}\right.$.)

\begin{tabular}{lcccc}
\hline \multicolumn{1}{c}{ Cultivar } & $\begin{array}{c}\text { Dry } \\
\text { matter }\end{array}$ & $\begin{array}{c}\text { Luteolin } \\
\text { derivatives }\end{array}$ & $\begin{array}{c}\text { Quercetin } \\
\text { derivatives }\end{array}$ & $\begin{array}{c}\text { Apigenin } \\
\text { derivatives }\end{array}$ \\
\hline Tornado green & $122.2 \pm 7.7 \mathrm{c}^{*}$ & $117.8 \pm 2.0 \mathrm{a}$ & $42.3 \pm 0.9 \mathrm{a}$ & $13.3 \pm 0.8 \mathrm{a}$ \\
Tornado red & $125.3 \pm 16.4 \mathrm{c}$ & $53.7 \pm 2.3 \mathrm{c}$ & $17.2 \pm 0.7 \mathrm{c}$ & $5.7 \pm 1.2 \mathrm{~b}$ \\
& & & & $4.0 \pm 0.1 \mathrm{c}$ \\
Tajfun green & $79.3 \pm 2.8 \mathrm{a}$ & $77.8 \pm 1.6 \mathrm{~b}$ & $27.1 \pm 3.0 \mathrm{~b}$ & $3.0 \pm 0.5 \mathrm{~d}$ \\
Tajfun red & $112 \pm 10.1 \mathrm{~b}$ & $31.7 \pm 1.1 \mathrm{~d}$ & $11.3 \pm 2.4 \mathrm{~d}$ & \\
\hline
\end{tabular}

* The results are means $(\mathrm{n}=9) \pm$ standard deviation. Different letters in the same column indicate significant differences between means $(\mathrm{P} \leq 0.05)$

Table 2

Phenolic acid derivatives, glycosides of flavonoids and capsaicinoid content in semi-hot pepper cultivars at two maturity stages $\left(\mu \mathrm{g} \mathrm{x} \mathrm{g}{ }^{-1} \mathrm{fw}.\right)$

\begin{tabular}{lccccc}
\hline \multicolumn{1}{c}{ Cultivar } & $\begin{array}{c}\text { Derivatives } \\
\text { of phenolic acids }\end{array}$ & $\begin{array}{c}O \text {-glycosylated } \\
\text { flavonoids }\end{array}$ & $\begin{array}{c}C \text {-glycosylated } \\
\text { flavonoids }\end{array}$ & $\begin{array}{c}\text { Capsaicin and } \\
\text { dihydrocapsaicin }\end{array}$ & $\begin{array}{c}\text { Total } \\
\text { of phenolics }\end{array}$ \\
\hline $\begin{array}{l}\text { Tornado green } \\
\text { Tornado red }\end{array}$ & $19.3 \pm 1.9 \mathrm{a}^{*}$ & $144.4 \pm 3.1 \mathrm{a}$ & $28.9 \pm 0.9 \mathrm{a}$ & $8.8 \pm 0.3 \mathrm{a}$ & 201.4 \\
& $80.1 \pm 4.4 \mathrm{~b}$ & $59.4 \pm 2.4 \mathrm{~b}$ & $17.2 \pm 0.8 \mathrm{~b}$ & $6.9 \pm 0.6 \mathrm{a}$ & 163.6 \\
Tajfun green & $31.9 \pm 1.5 \mathrm{c}$ & $90.8 \pm 3.4 \mathrm{c}$ & $18.0 \pm 0.8 \mathrm{~b}$ & $4.7 \pm 0.2 \mathrm{~b}$ & 145.4 \\
Tajfun red & $51.7 \pm 6.6 \mathrm{~d}$ & $34.7 \pm 2.6 \mathrm{~d}$ & $11.4 \pm 1.1 \mathrm{c}$ & $6.9 \pm 0.1 \mathrm{a}$ & 104.7 \\
\hline
\end{tabular}

* The results are means $(n=9) \pm$ standard deviation. Different letters in the same column indicate significant differences between means $(\mathrm{P} \leq 0.05)$ 
changes in phenolic content were found. There was noted a higher level of flavonoid derivatives and total phenolics at green maturity stage than at red ripe stage, while the changes of phenolic acid derivatives during pepper ripening were inverse. The concentration of these compounds increased four times in red fruits of cv. Tornado and $60 \%$ in cv. Tajfun when compared to the green fruits (Table 2).

It was also found that the $O$ - and $C$-glycosylated flavonoid content was higher in green fruits than in red ones in the two analyzed pepper cultivars (Table 2 ). Additionally, it was observed that the decomposition of $\mathrm{O}$-glycosylated derivatives of flavonoids was more dynamic than that of $C$-glycosylated derivatives. During fruit maturation, $O$-glycosylated flavonoid content decreased by about $60 \%$ in the two cultivars, when compared to green fruits. The highest concentrations of $O$-glycosylated flavonoids were noted in green fruits of cv. Tornado. The content of $C$-glycosylated flavonoids was lower than of $O$-glycosylated flavonoids, and during fruit ripening the levels of these compounds decreased by about $40 \%$ and $37 \%$ in cv. Tornado and Tajfun, respectively (Table 2). The capsaicinoid content increased about $47 \%$ during maturation of cv. Tajfun. In cv. Tornado a decrease in the concentration of these compounds was observed during ripening, but changes were not significant statistically.

\section{DISCUSSION}

Similar changes in the composition of phenolic compounds in pepper fruit during the maturation process were observed by other authors ( $\mathrm{S} \mathrm{u} \mathrm{kr}$ a s n o and Y e o m a n ; 1993; H o w a r d et al. 2000). Interesting conclusions may be drawn when our results are compared with those obtained by M a rin et al. (2004), who analyzed hydroxycinnamic acid derivatives and flavonoid content of sweet pepper at different maturity stages. They found that during fruit maturation both phenolic acid derivatives and $O$ - and $C$ - glycosylated flavonoids decreased. This is in disagreement with our results. It may be explained by the composition of these groups of compounds. In their work, $\mathrm{M}$ a r i n et al. (2004) found a compound called "caffeic acid derivative"; it was found in green fruits but was not detected in red ones. Up till now, we have not identified these compounds in the earlier analyzed fractions of hot peppers (M a ters ka and Perucka, 2005; Mate rs ka et al. 2003a, 2003b) and, in this study, we did not show them in the fractions derived from the semi-hot pepper cultivars. On this basis we conclude that these compounds occur mainly in sweet cultivars of pepper and determine the total of hydroxycinnamic acid derivatives in unripe fruits. The second difference between phenolic compound content in sweet and semihot pepper cultivars is the fact that in sweet pepper $C$-glycosylated flavonoids predominated (M a ri n et al. 2004), contrary to the results obtained in the present work where it was shown that $O$-glycosylated flavonoids occurred in a higher concentration in semi-hot pepper cultivars (Table 2). Studying the changes in the accumulation of $O$ - and $C$-glycosidic flavonoid derivatives during maturation of the fruits, we noted higher losses of $O$-glycosides than of $C$-glycosides (Table 2). $\mathrm{M}$ arin et al. (2008) showed that changes in $O$-and $C$-glycosidic derivatives of flavonoids in sweet peppers were comparable during maturation of the fruits. It may be explained by the fact that in sweet pepper cultivars changes in the content of phenolic compounds (hydoxycinnamic acids, $O$ - and $C$ - flavonoid derivatives) are less diverse than in semi-hot cultivars which also contain capsaicinoids.

The changes in capsaicinoid content during pepper fruit maturation were not sufficiently statistically significant at $\mathrm{P} \leq 0.05$ in $\mathrm{cv}$. Tornado, but in $\mathrm{cv}$. Tajfun we noticed an increase in the level of these compounds (Table 2). The results obtained earlier for hot peper cultivars and by other authors indicate that during fruit maturation the content of capsaicinoids decreased (S u krasno and Y e o man, 1993; P erucka, 1996; Contreras-Padilla and Yahia, 1998; Minami et al. 1998; Perucka and $\mathrm{M}$ ate r s k a, 2001). The same tendency was noticed in cv. Tornado (Table 2). The decline in capsaicinoid concentration was a result of chemical disintegration due to photooxidation (I w a i et al. 1979) or inhibition of capsaicinoid synthesis ( $\mathrm{Hal} 1$ and $\mathrm{Y}$ e o m a n, 1991). During maturation, the biosynthesis of glycosylated derivatives of phenolic acids increased, possibly instead of capsaicinoids and flavonoids.

Additionally, we observed similar changes in total phenolics in the present study (a 23\% decrease during maturation), likewise $\mathrm{M}$ arin et al. (2008) (a decrease of approx. 25\% during sweet pepper maturation). On this basis we may conclude that the accumulation of phenolic compound derivatives during the maturation process of pepper fruits changes in different ways - depending on the pungency of the fruit, but total phenolics decrease at a comparable level in the fruit of semi-hot and sweet pepper cultivars.

\section{CONCLUSIONS}

1. The accumulation of phenylpropanoids in pepper fruit of semi-hot cultivars related to the stage of fruit maturity. During maturation, total phenolics and the level of flavonoid derivatives decreased, but at the same time the accumulation of phenolic acid derivatives increased. 
2. In the fruit of semi-hot pepper cultivars, $O$-glycosides of flavonoids dominated in both maturity stages.

\section{REFERENCES}

Burda S., Oleszek W., 2001. Antioxidant and antiradical activities of flavonoids. J. Agric. Food Chem. 49: 27742779.

Contreras-Padilla M., Yahia E. M., 1998. Changes in capsaicinoids during development, maturation and sesenscence of chile peppers and relation with peroxidase activity. J. Agric. Food Chem. 46: 2075-2079.

Diaz J., Bernal A., Merino F., Ros Barcelo A., 1998. Phenolic metabolism in Capsicum annuum L. Rec. Res. Dev. Phytochem. 2: 155-169.

Fah s P. S. S., Faucher M. A., 2002. Nutriceuticals and cardiovascular health in women. J. Midwifery \& Women's Health, 47: 190-203.

Hall R. D., Ye om a n M. M., 1991. The influence of intracellural pools of phenylalanine derivatives upon the synthesis of capsaicin by immobilized cell cultures of chili pepper, Capsicum frutescens. Planta, 185: 72-80.

Harborne J. B., Willi a m s Ch. A., 2000. Advances in flavonoid research since 1992. Phytochemistry, 55: 481504.

Hornero-Mendez D., Gomez-Ladron R., Mingue z-Mosquera M. I., 2000. Carotenoid biosynthesis changes in five red pepper (Capsicum annuиm L.) cultivars during ripening. Cultivar selection for breeding. J. Agric. Food Chem. 48: 3857-3864.

How ard L. R., Talcott S. T., Brenes C. H., Villalon B., 2000. Changes in phytochemical and antioxidant activity of selected pepper cultivars (Capsicum species) as infuenced by maturity. J. Agric. Food Chem. 48: 1713-1720.

Iwai K., Suzuki T., Fujiwake H., 1979. Formation and accumulation of pungent principle of hot pepper fruits, capsaicin and its analogues in Capsicum annuum var. annuиm c.v. Karayatsubusa at different growth stages after flowering. Agric. Biol. Chem. 43: 2493-2498.

Kogure K., Goto S., Nishimura M., Yasumoto M., Abe K., Ohiwa Ch., Sassa H., Kusumi T., Terada H., 2002. Mechanism of potent antiperoxidative effect of capsaicin. Bioch. Bioph. Acta, 1573: 84-92.

Lee J. S., Ch ang J. S., Lee J. Y., K i m J. A., 2004. Capsaicin-induced apoptosis and reduced release of reactive oxygen species in MBT-2 murine bladder tumor cells. Arch. Pharm. Res. 27: 1147-1153.

Long A.C., Medeiros D. M., 2001. Evaluation of capsaicin use in analgesic medicine. J. Nutraceuticals, 3: 39-46.

Marin A., Ferreres F., Tomas-Barberan F. A., Gil M. I., 2004. Characterization and quantitation of antioxidant constituents of sweet pepper (Capsicum annuum L.). J. Agric. Food Chem. 52: 3861-3869.
Marin A., Gil M. J., Flores P., Selma M. V., 2008. Microbial quality and bioactive constituents of sweet peppers from sustainable production systems. J. Agric. Food Chem. 56: 11334-11341.

Materska M., Perucka I., 2005. Antioxidant activity of the main phenolic compounds isolated from hot pepper fruit (Capsicum annuum L.). J. Agric. Food Chem. 53: 1750-1756.

Materska M., Perucka I., S to chmal A., Piacente S., Oleszek W., 2003a. Quantitative and qualitative determination of flavonoids and phenolic acid derivatives from pericarp of hot pepper fruit cv. Bronowicka Ostra. Pol. J. Food Nutr. Sci. 12/53, SI 2: 72-76.

Materska M., Piacente S., Stochmal A., Pizza C., Oles zek W., Per u ck a I., 2003b. Isolation and structure elucidation of flavonoid and phenolic acid glycosides from pericarp of hot pepper fruit Capsicum annuum L. Phytochemistry, 63: 893-898.

Minami M., Toyota M., Inoue T., Nemoto K., Ujihar a A., 1998. Changes of capsaicinoid contents during maturing stage in chili pepper (Capsicum spp.). J. Faculty Agric. Shinshu Univ. 35: 45-49.

Minguez-Mosquera M. I., Perez-Galvez A., Garrido-Fernandez J., 2000. Carotenoid content of the varieties Jaranda and Jariza (Capsicun annuum L.) and response during the industrial slow drying and grinding steps in paprika processing. J. Agric. Food Chem. 48: 2972-2976.

Morre D. J., Sun E., Geilen C., Wu L. Y., deCabo R., Krasagakis K., Orfanos C. E., Morre D. M., 1996. Capsaicin inhibits plasma membrane NADH oxidase and growth of human and mouse melanoma lines. E. J. Cancer, 32A (11): 1995-2003.

Peruck a I., 1996. Effect of 2-chloroethylphosphonic acid on phenylalanine ammonia-lyase activity and formation of capsaicinoids in placenta of hot pepper fruits. Acta Phys. Plantarum, 18: 7-12.

Perucka I., Materska M., 2001. Phenylalanine ammonia lyase and antioxidant activities of lipophilic fraction of fresh pepper fruits Capsicum annuum L. Innov. Food Sci. Emerging Tech. 2: 189-192.

Rice-Evans C. A., Miller J., Paganga G., 1997. Antioxidant properties of phenolic compounds. Trends in Plant Sci. 2: 152-159.

Row land I., 1999. Optimal nutrition: fiber and phytochemicals. Proc. Nutr. Soc. 58 (2): 415-419.

Shetty K., 2004. Role of proline-linked pentose phosphate pathway in biosynthesis of plant phenolics for functional food and environmental applications: a review. Proc. Bioch. 39: 789-803.

Stochmal A., Piacente S., Pizza C., De Riccardis F., Leitz R., Oles zek W., 2001. Alfalfa (Medicago sativa $\mathrm{L}$.) flavonoids. 1. Apigenin and luteolin glycosides from aerial parts. J. Agric. Food Chem. 49: 753-758.

S u k r a s n o N., Ye o m an M. M., 1993. Phenylpropanoid metabolism during growth and development of Capsicum frutescens fruits. Phytochemistry, 32: 839-844. 
Szolcsanyi J., 2004. Forty years in capsaicin research for sensory pharmacology and physiology. Neuropeptides, 38: 377-384

Yalpani N., Enyedi A. J., Leon J., Raskin I., 1994. Ultraviolet light and ozone stimulate accumulation of salicylic acid pathogenesis-related proteins and virus resistance in tobacco. Planta, 193: 372-376.

\section{Akumulacja fenylopropanoidów w zielonych i czerwonych owocach półostrych odmian papryki Capsicum annuum $\mathrm{L}$.}

\section{Streszczenie}

Celem przedstawionej pracy było określenie różnic w zawartości $C$ i $O$ glikozydów flawonoidowych, pochodnych kwasów fenolowych oraz kapsaicynoidów w dwóch półostrych odmianach papryki Tornado i Tajfun. Owoce zbierano w dwóch fazach dojrzałości: w dojrzałości technologicznej (wykształcone zielone) oraz w pełni dojrzałe (czerwone). Frakcje flawonoidów i kapsaicynoidów izolowano metodą ekstrakcji do fazy stałej na mikrokolumnach Sep-Pak C18 za pomocą $40 \%$ i $70 \%$ roztworu metanolu. Skład chemiczny obu frakcji określano metodą HPLC, wykorzystując jako wzorce związki otrzymane we wcześniejszej pracy. Frakcja flawonoidów zawierała estry glukozowe kwasów fenolowych, głównie ferulowego i synapinowego oraz pochodne flawonoidów kwercetyny, luteoliny i apigeniny. Związki te występowały w połączeniach z glukozą, ramnozą i apiozą jako $O$ - i $C$ - glikozydy. Frakcja kapsaicynoidów zawierała głównie kapsaicynę i dihydrokapsaicynę. Stwierdzono, że w owocach zielonych dominującymi związkami fenolowymi były $O$ - glikozydy flawonoidowe i kapsaicynoidy, podczas gdy w owocach czerwonych pochodne kwasów fenolowych. Ponadto stwierdzono szybszą degradację $O$-glikozydowych pochodnych flawonoidów w porównaniu do $C$-glikozydowych w trakcie dojrzewania owoców półostrych odmian papryki. 